\title{
DAYA SAING EKSPOR PRODUK PERIKANAN INDONESIA DI LINGKUP ASEAN DAN ASEAN-CHINA
}

\author{
Subhechanis Saptanto \\ Balai Besar Riset Sosial Ekonomi Kelautan dan Perikanan \\ JI. KS. Tubun Petamburan VI Jakarta 10260 \\ Telp. (021) 53650162, Fax. (021)53650159 \\ Diterima 6 Januari 2011 - Disetujui 21 Mei 2011
}

\begin{abstract}
ABSTRAK
Keunggulan komparatif dapat digunakan sebagai indikator besarnya daya saing suatu negara dalam perdagangan internasional. Penelitian ini bertujuan untuk menganalisis daya saing ekspor perikanan Indonesia di tingkat ASEAN dan ASEAN-China. Kajian ini menggunakan data sekunder time series yang dikeluarkan oleh United Nation Comtrade dari tahun2000 hingga 2008. Metode analisis yang digunakan adalah dengan metode Revealed Comparative Advantage (RCA). Hasil penelitian menunjukkan bahwadi tingkat ASEAN maupun ASEAN-China, produk perikanan Indonesia yang memiliki daya saing adalah produk dengan kode HS 03 (ikan, udang-udangan, hewan lunak, invertebrata perairan), HS 710110 (mutiara dari alam yang belum diolah), HS 710121 (mutiara budidaya yang belum diolah), dan HS 121220 (rumput laut dan alga lainnya). Hal ini menunjukkan bahwa Indonesia masih lemah dalam hal ekspor produk yang memiliki nilai tambah.
\end{abstract}

Kata Kunci: daya saing, ekspor, produk perikanan

\section{Abstract : Comparative Advantage of Indonesian Fisheries Product in ASEAN and ASEAN-China. by : Subhechanis Saptanto}

Comparative advantage can used as indicator of trade level in international trade. This study aim to analyze comparative advantageof Indonesian fisheries product in both of ASEAN and ASEAN-China. This study used secondary data of UN Comtrade from 2000 until 2008 and revealed comparative advantage (RCA) method. Results of this study show that in both of ASEAN and ASEAN-China, for HS 03 (Fish, crustaceans, molluscs, aquatic invertebrates), HS 710110 (Pearls natural, not permanently mounted or set), HS 710121 (pearls cultured unprocessed), and HS 121220 (seaweeds and other algae), Indonesia still vave comparative advantage in fisheries product. This results indicate that Indonesia considers a weak position in the valued added export of the fisheries product.

Keywords : comparative advantage, export, fisheries product 


\section{PENDAHULUAN}

Indonesia merupakan salah satu negara yang memiliki sumber daya perikanan yang melimpah baik yang berasal dari subsektor perikanan tangkap maupun perikanan budidaya. Menurut data statistik yang dikeluarkan oleh Departemen Kelautan dan Perikanan pada tahun 2007, Indonesia memiliki produksi sebesar 8.238.302 ton dari perikanan tangkap dan budidaya dengan rata-rata pertumbuhan sebesar 2,07\% pertahun (DKP, 2009). Produksi perikanan yang melimpah tersebut, sebagian digunakan untuk memenuhi kebutuhan dalam negeri dan sebagian lagi diekspor. Ekspor merupakan salah satu komponen untuk meningkatkan kesejahteraan rakyat karena memberikan sumbangan devisa dalam rangka pembangunan ekonomi. Komoditas perikanan yang umumnya diekspor adalah tuna, udang, rumput laut, mutiara, kerapu, dan produk ikan olahan.

Salah satu fenomena perdagangan internasional berupa pembentukan blokblok ekonomi seperti kerjasama ASEAN, Uni Eropa, APEC dan NAFTA merupakan upaya untuk mengantisipasi liberalisasi perdagangan dalam rangka memperkuat perekonomian suatu negara atau kelompok negara. Liberalisasi perdagangan tersebut dapat memberikan dampak pada negara eksportir maupun importir perikanan. Salah satu dampak yang ditimbulkan adalah negara pengimpor akan menurunkan tarif impor sehingga dapat meningkatkan impor komoditas atau produk perikanan sedangkan negara pengekspor perikanan akan menurunkan/menghapus subsidi perikanan. Negara tersebut akan mengurangi kemampuan ekspor perikanannya ke pasar internasional, sehingga menjadi net importir (Asnawi dan Sastrawidjadja, 2007), sehingga dapat memperbesar peluang pasar internasional.

Indonesia memiliki keunggulan komparatif (comparative advantage) maupun keunggulan daya saing kompetitif (competitive advantage) dalam sektor perikanan dan juga memiliki prospek pasar domestik (peningkatan konsumsi ikan nasional) dan pasar internasional (peningkatan ekspor perikanan).

Keuntungan dari perdagangan internasional produk perikanan Indonesia saat ini perlu dicermati kembali dengan mulai diberlakukannya AFTA pada tahun 2003 dan ACFTA pada tahun 2004. Kondisi ini memunculkan suatu pertanyaan apakah daya saing ekspor perikanan Indonesia masih tinggi dengan adanya isu ACFTA yang disinyalir dapat mengakibatkan kalah bersaingnya produk perikanan Indonesia.

Indonesia harus memiliki daya saing yang tinggi agar masih tetap mampu mendapatkan manfaat dari perdagangan internasional. Produk perikanan yang memiliki daya saing yang tinggi sangat diharapkan untuk dapat terus eksis dan berkembang sehingga ekspornya makin meningkat dan dapat mendorong produksi dalam negeri serta meningkatkan pendapatan nelayan/pembudidaya ikan, kesempatan kerja dan juga devisa negara. Produk perikanan yang memiliki daya saing rendah perlu dikaji lebih dalam lagi, seperti mengapa hal tersebut terjadi dan apa yang harus dilakukan agar daya saingnya meningkat sehingga komoditas tersebut tetap dapat diekspor.

Oleh karena itu sangat penting untuk dilakukan suatu kajian terhadap daya saing produk perikanan Indonesia di lingkup kerjasama China ASEAN. Penelitian ini bertujuan untuk mengetahui daya saing produk perikanan Indonesia di lingkup ASEAN dan ASEAN-China melalui sebuah kajian terhadap kinerja perdagangan produk perikanan Indonesia.

\section{METODOLOGI}

Hady dalam Syah (2000) menjelaskan bahwa menurut David Ricardo tidak semua negara memiliki keunggulan absolut seperti yang ada pada teori Adam Smith. Oleh karena 
itu, suatu negara lebih baik menspesialisasikan diri pada produk yang memiliki keunggulan komparatif yang mencerminkan sebuah indeks daya saing yang memiliki penekanan keunggulan pada biaya tenaga kerja dibandingkan pada faktor produksi lainnya.

Salah satu metode yang dapat digunakan untuk mengukur keunggulan komparatif adalah metode Revealed Comparative Advantage (RCA)(Balassa, 1965). Metode ini memiliki kelemahan, karena bersifat statis dan menggunakan asumsi bahwa setiap negara mengekspor semua komoditas atau kelompok komoditas yang diperdagangkan. Meskipun demikian, nilai indeks RCA yang dihasilkan cukup menggambarkan keunggulan komparatif produk/komoditas sebuah negara.

Meskipun suatu negara dapat memproduksi semua barang-barang kebutuhannya dengan lebih efisien dibandingkan dengan negara lain tetapi perdagangan antar negara tetap menguntungkan kedua belah pihak yang menekankan pada comparative cost bukan absolute cost. Suatu negara dapat bekerja lebih efisien dan menguntungkan bila hanya menspesialisasikan produk yang di negaranya memiliki keunggulan komparatif untuk diekspor dan mengimpor produk yang tidak memiliki keunggulan komparatif.

Adanya perbedaan atau keunggulan komparatif dan spesialisasi ini yang memungkinkan terjadinya proses perdagangan. Oleh karena itu upaya untuk melihat potensi dan perkembangan dari komoditas yang dapat diunggulkan dalam perdagangan harus dapat melihat permasalahan dari sisi keunggulan komparatif serta kemampuannya dalam menghadapi pasar internasional. Metode yang digunakan dalam penelitian ini melalui pendekatan permasalahan yang mampu menunjukkan keunggulan komparatif dan daya saing. Salah satu metode yang dapat digunakan untuk mengukur keunggulan komparatif adalah metode RCA. Nilai dari RCA dapat juga dikatakan sebagai salah satu faktor yang dapat menentukan kemampuan dalam menggambarkan pangsa pasar ekspor. Nilai dari indeks ini menunjukkan perbandingan antara pangsa ekspor komoditas atau sekelompok komoditas suatu negara terhadap pangsa ekspor komoditas tersebut dari seluruh dunia. Sehingga indeks tersebut dapat memberikan informasi mengenai posisi perdagangan luar negeri suatu negara. Hasil perhitungan RCA akan menunjukkan posisi relatif keunggulan komparatif komoditas perikanan Indonesia terhadap kinerja ekspor secara menyeluruh.

\section{Jenis dan Sumber Data}

Data yang digunakan dalam kajian ini adalah data sekunder yang berasal dari UN Comtrade (http://comtrade.un.org/) yaitu data nilai ekspor perikanan negara-negara anggota ASEAN dan China ke dunia dari tahun 2000 hingga 2008. Komoditas perikanan yang digunakan berdasarkan Harmonized System dapat dilihat pada Tabel 1.

\section{Tabel 1. Komoditas Ekspor Perikanan Indonesia Berdasarkan Kode HS Table 1.Fisheries Export Commodities of Indonesia by HS Code}

\begin{tabular}{cll}
\hline No & Kode/Code & \multicolumn{1}{c}{ Keterangan/Notes } \\
\hline 1 & HS 03 & Fish, crustaceans, molluscs, aquatic invertebrates \\
2 & HS 1603 & Extracts, juices of meat, fish, aquatic invertebrates \\
3 & HS 1604 & Prepared or preserved fish, fish egg, caviar \\
4 & HS 1605 & Crustaceans, molluscs, etc, prepared or preserved \\
5 & HS 121220 & Seaweeds and other algae \\
6 & HS 051191 & Fish, shellfish and crustaceans/non-food \\
7 & HS 710110 & Pearls natural, not permanently mounted or set \\
8 & HS 710121 & Pearls cultured unworked \\
9 & HS 710122 & Pearls cultured worked, not mounted or set \\
\hline
\end{tabular}

Sumber: UN Comtrade/Source : UN Comtrade 


\section{Metode Pengumpulan Data}

Pengumpulan data dilakukan dengan cara mengunduh data-data ekspor perikanan dari negara-negara yang tergabung dalam ASEAN dan China melalui situs Comtrade. Data-data lainnya berasal dari Kementerian Kelautan dan Perikanan yang mendukung kegiatan penelitian.

\section{Metode Analisis Data}

Kinerja perdagangan perikanan dilihat dari share ekspor nilai perikanan dengan formula sebagai berikut :

$$
\operatorname{ShX}(\%)=\frac{X_{\ddot{j}}}{X_{T o t}}
$$

Dimana:

Sh X : Share ekspor dari suatu negara/Export Share of a Country

$\mathrm{X}_{i j}$ : Nilai Ekspor dari suatu negara i dengan komoditas perikanan $\mathrm{j} /$ Export value of a country $i$ and fisheries commodities $j$

$\mathrm{X}_{\text {Tot }}$ : Nilai ekspor total /Total of export value

Penghitungan keunggulan komparatif dapat dilihat dari nilai RCA dimana menurut Balassa (1965) dituliskan sebagai berikut :

$R C A=\left(X_{i j} / X_{i t}\right) /\left(X_{n j} / X_{n t}\right)=\left(X_{i j} / X_{n j}\right) /\left(X_{i t} / X_{n t}\right) \ldots$

RCA : Index daya saing/ RCA (Revealed Comparative Advantage)Index

$\mathrm{X}_{\mathrm{ij}}$ : Nilai Ekspor dari negara i dengan komoditas perikanan $\mathrm{j} /$ Export value of a country $i$ with Fisheries commodities $j$

$X_{i t}$ : Nilai ekspor dari negara i dengan kumpulan komoditas perikanan $\mathrm{t} /$ Export value of a country $i$ with group of countries $t$

$X_{n j}$ : Nilai Ekspor dari kumpulan negara $\mathrm{n}$ dengan komoditas perikanan $\mathrm{j} /$ Export value of countries group $n$ with fisheries commodities $j$ of countries $t$
$X_{n t}$ : Nilai Ekspor dari kumpulan negara $\mathrm{n}$ dengan kumpulan komoditas perikanan t/Export value of countries group $n$ with group of countries $t$

RCA > 1: Memiliki keunggulan komparatif, produk dipacu untuk berorientasi ekspor (daya saing tinggi)/ Has comparative advantage, accelerating product for export oriented

RCA $<1$ : Tidak memiliki keunggulan komparatif, produk sebaiknya tidak berorientasi ekspor (daya saing rendah)/Has no comparative advantage, no accelerating product for export oriented

\section{HASIL DAN PEMBAHASAN}

\section{Kinerja Perdagangan Perikanan Indonesia-} ASEAN-China

China-ASEAN Free Trade Agreement (ACFTA) merupakan kawasan perdagangan bebas yang pertama hasil negosiasi Cina dengan luar negeri dan adalah zona perdagangan bebas yang paling besar di dunia dan terdiri dari negara-negara berkembang. Kawasan tersebut mempunyai populasi 1,9 miliar orang, PDBnya hampir 6 triliun Dolar Amerika Serikat dan nilai volume total perdagangan 4,5 triliun Dolar Amerika Serikat. Kawasan tersebut resmi dilaksanakan pada tanggal 1 Januari tahun 2010. Sejak digulirkannya pembangunan kawasan perdagangan bebas, Cina dengan Indonesia, Brunei Darussalam, Filipina, Malaysia, Thailand, dan Singapura memberlakukan tarif nol persen terhadap 90 persen produk. Sampai tahun 2015, liberalisasi perdagangan antara Cina dengan empat (4) negara ASEAN, yaitu Vietnam, Laos, Kamboja dan Myanmar akan mencapai taraf yang sama.

Indonesia menduduki peringkat kedua di tingkat ASEAN dalam hal ekspor perikanan ke dunia dengan nilai rata-rata ekspor sebesar 1,84 milyar Dolar Amerika Serikat pada periode tahun 2000 hingga 2008 (UN Comtrade, 2010). Komoditas 03 
(ikan, kepiting, hewan lunak, invertebrata perairan) memiliki share ekspor tertinggi yakni sebesar $85 \%$. Hal ini menunjukkan bahwa Indonesia masih sangat tergantung pada ekspor ikan segar dan kurang mengekspor ikan yang memiliki nilai tambah.

Berdasarkan hasil analisis dari data UN Comtrade, negara ASEAN lainnya yaitu Thailand menempati peringkat pertama ekspor produk perikanan dengan nilai sebesar 4,65 milyar dolar dan seperti Indonesia, komoditas 03 juga memiliki share ekspor tertinggi bagi Thailand yakni sebesar $44 \%$ (dapat dilihat pada Lampiran 1). Namun demikian, share komoditas 1604 (29\%) berupa ikan, telur ikan, olahan caviar dan komoditas 1605 (26\%) berupa udang-udangan, olahan hewan lunak lainnya yang dihasilkan oleh Thailand juga cukup tinggi. Hal ini menunjukkan bahwa Thailand tidak hanya bergantung pada ekspor ikan segar namun juga mengekspor ikan yang memiliki nilai tambah (diversifikasi ekspor) dalam jumlah yang cukup besar. Selain Thailand, negara lain yang memiliki ekspor produk perikanan yang memiliki nilai tambah adalah Filipina dimana untuk komoditas 1604 , share ekspornya sebesar $26 \%$.

China yang telah melakukan kesepakatan dengan ASEAN dalam kerjasama ACFTA memiliki nilai ekspor perikanan yang cukup tinggi yaitu sekitar 6,90 milar dolar. Share ekspor komoditas perikanan Cina untuk komoditas 03 adalah sebesar 55\%. Sedangkan untuk komoditas 1604 dan 1605 masingmasing sebesar $20 \%$ dan $22 \%$. Gambar 1 menunjukkan besarnya rata-rata nilai ekspor perikanan di kawasan ASEAN dan juga negara China dari tahun 2000 hingga 2008.

\section{Kinerja Daya Saing Produk Perikanan}

Kinerja daya saing produk perikanan yang ditunjukkan oleh nilai RCA berdasarkan penelitian yang dilakukan oleh PKSPL-IPB dan Bappenas dalam Karim (2008) dapat dilihat pada Tabel 2.

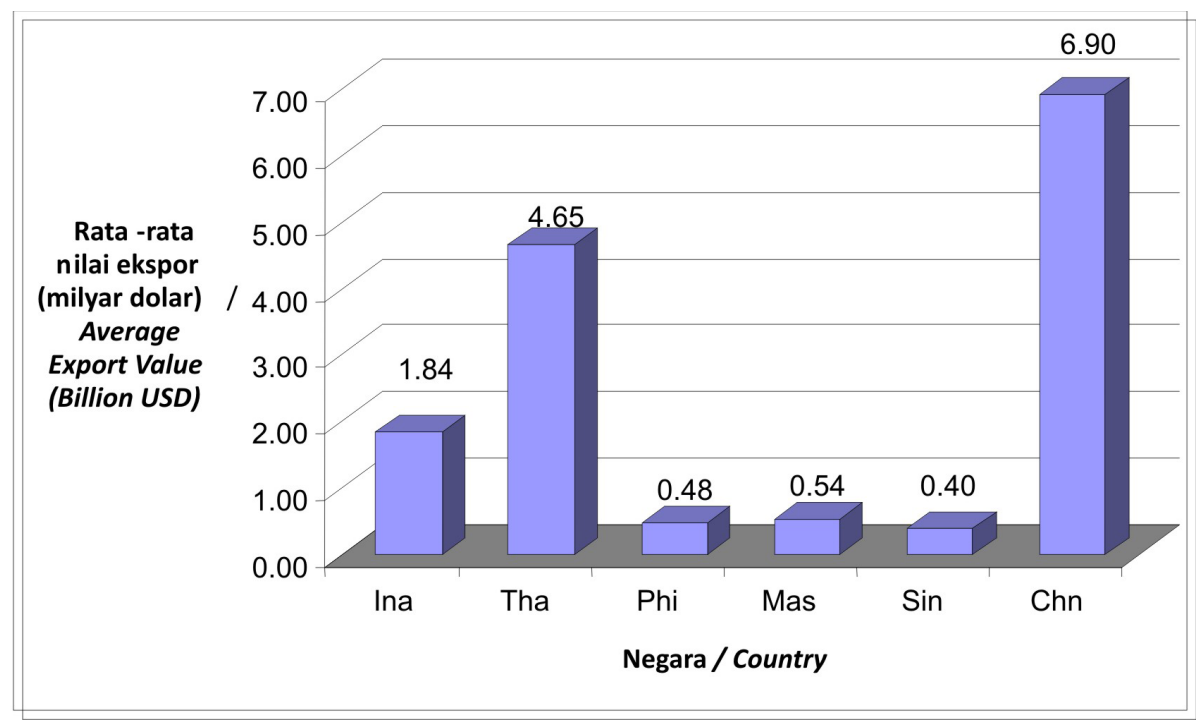

Sumber : UN Comtrade, 2010 (diolah)/Source : UN Comtrade, 2010 (processed)

Gambar 1. Rata-Rata Nilai Ekspor Perikanan ASEAN-China, 2000-2008 Figure 1. Average of Value in Exporting Fisheries Product of ASEAN- China, 2000-2008 
Tabel 2. Nilai RCA Komoditas Perikanan Indonesia, 2005

Table 2. RCA Value of Fisheries Commodities of Indonesia, 2005

\begin{tabular}{|c|c|c|c|}
\hline No & $\begin{array}{l}\text { Komoditas Perikanan/ } \\
\text { Fisheries Commodities }\end{array}$ & RCA & $\begin{array}{l}\text { Kompetitor/ } \\
\text { Competitor }\end{array}$ \\
\hline 1. & $\begin{array}{l}\text { a. Tuna fresh or chilled, whole } \\
\text { b. Crabs, not frozen } \\
\text { c. Shrimp and prawn frozen }\end{array}$ & $\begin{array}{l}38.9 \\
28.5 \\
13.6\end{array}$ & $\begin{array}{l}\text { Phillipines dan Australia } \\
\text { China and England } \\
\text { India and Thailand }\end{array}$ \\
\hline 2. & Crustacean & 10.5 & Canada and India \\
\hline 3. & Crustacean nes, frozen & 10.4 & Denmark and Ireland \\
\hline 4. & $\begin{array}{l}\text { a. Tuna nes, fresh or chilled, whole } \\
\text { b. Skipjack, stripe-belly bonito, fresh or } \\
\text { chilled } \\
\text { c. Eels, fresh or chilled, whole }\end{array}$ & $\begin{array}{l}5.6 \\
0.7 \\
0.0\end{array}$ & $\begin{array}{l}\text { Croatia dan USA } \\
\text { Turkey dan Venezuela } \\
\text { Spain and England }\end{array}$ \\
\hline 5. & $\begin{array}{l}\text { Rock lobster and other sea craw fish, } \\
\text { not frozen }\end{array}$ & 2.5 & South Africa and Mexico \\
\hline
\end{tabular}

Sumber: Karim (2008)/Source : Karim (2008)

Berdasarkan Tabel 2 diperoleh informasi bahwa komoditas perikanan yang diekspor adalah tuna, cakalang, udang, kepiting, belut, dan lobster. Nilai RCA yang tertinggi adalah tuna. Untuk lebih lengkapnya dapat diuraikan sebagai berikut : (i). nilai RCA yang menempatkan Indonesia dalam peringkat pertama di pasar internasional adalah untuk komoditas tuna (tuna fresh or chilled, whole); kepiting (crabs, not frozen); dan udang (shrimp and prawn frozen), RCA masingmasing 38,$9 ; 28,5$ dan 13,6 . Kompetitor komoditas tuna yaitu Filipina dan Australia. Sementara kompetitor komoditas kepiting adalah China dan Inggris (UK). Untuk komoditas udang yang menjadi kompetitornya adalah India dan Thailand; (ii) nilai RCA yang menempatkan Indonesia peringkat kedua adalah kepiting segar (Crustacean) dengan RCA sebesar 10,5. Kompetitor Indonesia hanyalah Canada dan India; (iii) nilai RCA yang menempatkan Indonesia peringkat ketiga adalah kepiting beku (crustacean nes, frozen) dengan RCA sebesar 10,4. Negara kompetitornya adalah Denmark dan Irlandia; (iv) nilai RCA yang menempatkan Indonesia peringkat keempat adalah tuna (tuna nes, fresh or chilled, whole); cakalang (skipjack, stripe-belly bonito, fresh or chilled, whole); dan belut (eels, fresh or chilled, whole) dengan nilai RCA masing-masing 5,6; 0,7; dan 0,00. Komoditas tuna nes, fresh or chilled, whole; kompetitornya Kroasia dan Amerika Serikat (USA). Sementara komoditas skipjack, stripe-belly bonito, fresh or chilled, whole kompetitornya Turki dan Venezuela, sedangkan komoditas Eels, fresh or chilled, whole kompetitornya adalah Spanyol dan Inggris (UK); (v) nilai RCA yang menempatkan Indonesia peringkat kelima adalah jenis lobster (rock lobster and other sea craw fish, not frozen) dengan nilai RCA sebesar 2,5, kompetitornya Afrika Selatan dan Mexico. Hasil analisis ini menunjukkan bahwa komoditas perikanan Indonesia memiliki daya saing yang tinggi di pasar internasional.

Indonesia memiliki keunggulan komparatif untuk empat (4) komoditas, yaitu HS 03, HS 710110, HS 710121 dan HS 121220 (Tabel 3). Untuk Thailand keunggulan ada pada dua (2) komoditas yakni HS 1604 dan HS 1605. Filipina memiliki keunggulan pada empat (4) komoditas yaitu HS 03, HS 1604, HS 710122 dan HS 121220. Untuk negara Singapura keunggulannya pada lima (5) komoditas yaitu HS 03, HS 1603, HS 051191, 
Tabel 3. Rataan Nilai RCA Produk Perikanan Negara-Negara Anggota ASEAN, 2000-2008 Table 3. Average of RCA Value in Fisheries Product of ASEAN Countries, 2000-2008

\begin{tabular}{|c|c|c|c|c|c|c|c|}
\hline \multirow{2}{*}{ No } & \multirow{2}{*}{$\begin{array}{l}\text { Komoditas/ } \\
\text { Commodities }\end{array}$} & \multirow{2}{*}{$\begin{array}{l}\text { Nama Komoditas/ } \\
\text { Name of Commodities }\end{array}$} & \multicolumn{5}{|c|}{ RCA } \\
\hline & & & Indonesia & Thailand & Phillipines & Singapore & Malaysia \\
\hline 1 & 03 & $\begin{array}{l}\text { Fish, crustaceans, } \\
\text { molluscs, aquatic } \\
\text { invertebrates }\end{array}$ & 1.44 & 0.75 & 1.02 & 1.36 & 1.36 \\
\hline 2 & 1603 & $\begin{array}{l}\text { Extracts, juices of } \\
\text { meat, fish, aquatic } \\
\text { invertebrates }\end{array}$ & 0.13 & 0.61 & 0.00 & 2.45 & 7.15 \\
\hline 3 & 1604 & $\begin{array}{l}\text { Prepared or preserved } \\
\text { fish, fish egg, caviar }\end{array}$ & 0.30 & 1.38 & 1.18 & 0.36 & 0.50 \\
\hline 4 & 1605 & $\begin{array}{l}\text { Crustaceans, molluscs, } \\
\text { etc, prepared or } \\
\text { preserved }\end{array}$ & 0.32 & 1.47 & 0.27 & 0.33 & 0.45 \\
\hline 5 & 051191 & $\begin{array}{l}\text { Fish, shellfish and } \\
\text { crustaceans/non-food }\end{array}$ & 0.12 & 0.64 & 0.26 & 11.32 & 0.61 \\
\hline 6 & 710110 & $\begin{array}{l}\text { Pearls natural, not } \\
\text { permanently mounted } \\
\text { or set }\end{array}$ & 1.65 & 0.40 & 0.61 & 5.53 & 0.85 \\
\hline 7 & 710121 & $\begin{array}{l}\text { Pearls cultured } \\
\text { unworked }\end{array}$ & 4.00 & 0.01 & 0.73 & 0.44 & 0.00 \\
\hline 8 & 710122 & $\begin{array}{l}\text { Pearls cultured worked, } \\
\text { not mounted or set }\end{array}$ & 0.29 & 0.54 & 6.91 & 3.62 & 0.06 \\
\hline 9 & 121220 & $\begin{array}{l}\text { Seaweeds and other } \\
\text { algae }\end{array}$ & 1.92 & 0.04 & 7.58 & 0.31 & 0.69 \\
\hline Rat & rata/Average & & 1.13 & 0.65 & 2.06 & 2.86 & 1.30 \\
\hline
\end{tabular}

Sumber : UN Comtrade, 2010 (diolah)/Source : UN Comtrade, 2010 (processed)

HS 710110 dan HS 710122. Posisi yang terakhir adalah Malaysia dengan keunggulan pada dua (2) komoditas yaitu HS 03, HS 1603. Secara rata-rata keseluruhan komoditas Indonesia masih memiliki keunggulan komparatif karena memiliki nilai $>1$ sedangkan Thailand memiliki nilai $<1$ dan dianggap kurang memiliki keunggulan komparatif meski nilai ekspornya paling besar bila dibandingkan dengan negara lain dalam ASEAN. Hal ini mengindikasikan bahwa Indonesia masih memiliki peluang untuk mengekspor ikan segar, mutiara dan rumput laut tetapi sangat disayangkan produk perikanan yang memiliki nilai tambah kurang berdaya saing ekspor. Kiranya perlu terus diupayakan peningkatan mutu sehingga produk perikanan Indonesia dapat memilik daya saing.
Bila China dimasukkan ke dalam analisis RCA terkait dengan adanya ACFTA maka diperoleh hasil RCA seperti pada Tabel 4. Hasil analisis pada Tabel 4 tersebut menunjukkan nilai rata-rata RCA produk perikanan dari lima negara anggota Asean dan China dari tahun 2000 hingga 2008. Hal ini dimaksudkan untuk melihat apakah dengan adanya China sebagai salah satu pengekspor ikan terbesar di dunia tidak merubah daya saing ekspor perikanan Indonesia di dunia atau sebaliknya.

Pada Tabel 4 terlihat bahwa masuknya China menjadikan Indonesia secara umum naik nilai RCA dari 1,13 menjadi 1,57 . Komoditas perikanan yang berdaya saing seluruhnya sama dengan komoditas yang ada di Tabel 1 . 
Tabel 4. Rataan Nilai RCA Produk Perikanan Negara-Negara Anggota ASEAN - China, 2000-2008 Table 4. Average of RCA Value in Fisheries Product of ASEAN-China, 2000-2008

\begin{tabular}{|c|c|c|c|c|c|c|c|c|}
\hline \multirow{2}{*}{ No } & \multirow{2}{*}{$\begin{array}{l}\text { Komoditas/ } \\
\text { Commodities }\end{array}$} & \multirow{2}{*}{$\begin{array}{c}\text { Nama } \\
\text { Komoditas/ } \\
\text { Name of } \\
\text { Commodities }\end{array}$} & \multicolumn{6}{|c|}{ RCA } \\
\hline & & & Indonesia & Thailand & Phillipines & Singapore & Malaysia & China \\
\hline 1 & 03 & $\begin{array}{l}\text { Fish, crustaceans, } \\
\text { molluscs, aquatic } \\
\text { invertebrates }\end{array}$ & 1.47 & 0.77 & 1.04 & 1.39 & 1.40 & 0.97 \\
\hline 2 & 1603 & $\begin{array}{l}\text { Extracts, juices of } \\
\text { meat, fish, aquatic } \\
\text { invertebrates }\end{array}$ & 0.11 & 0.51 & 0.00 & 1.98 & 5.85 & 1.22 \\
\hline 3 & 1604 & $\begin{array}{l}\text { Prepared or } \\
\text { preserved fish, fish } \\
\text { egg, caviar }\end{array}$ & 0.30 & 1.42 & 1.21 & 0.37 & 0.50 & 1.00 \\
\hline 4 & 1605 & $\begin{array}{l}\text { Crustaceans, } \\
\text { molluscs, etc, } \\
\text { prepared or } \\
\text { preserved }\end{array}$ & 0.27 & 1.39 & 0.24 & 0.31 & 0.44 & 1.04 \\
\hline 5 & 051191 & $\begin{array}{l}\text { Fish, shellfish and } \\
\text { crustaceans/non- } \\
\text { food }\end{array}$ & 0.13 & 0.77 & 0.32 & 11.91 & 0.66 & 0.80 \\
\hline 6 & 710110 & $\begin{array}{l}\text { Pearls natural, } \\
\text { not permanently } \\
\text { mounted or set }\end{array}$ & 2.83 & 0.75 & 1.09 & 10.08 & 1.57 & 0.09 \\
\hline 7 & 710121 & $\begin{array}{l}\text { Pearls cultured } \\
\text { unworked }\end{array}$ & 7.24 & 0.01 & 1.42 & 0.85 & 0.01 & 0.05 \\
\hline 8 & 710122 & $\begin{array}{l}\text { Pearls cultured } \\
\text { worked, not } \\
\text { mounted or set }\end{array}$ & 0.18 & 0.24 & 3.52 & 2.01 & 0.03 & 1.55 \\
\hline 9 & 121220 & $\begin{array}{l}\text { Seaweeds and } \\
\text { other algae }\end{array}$ & 1.57 & 0.04 & 5.58 & 0.23 & 0.50 & 1.30 \\
\hline \multicolumn{2}{|c|}{ Rata-rata/Average } & & 1.57 & 0.65 & 1.60 & 3.24 & 1.22 & 0.89 \\
\hline
\end{tabular}

Sumber : UN Comtrade, 2010 (diolah)/Source : UN Comtrade, 2010 (processed)

Untuk Thailand nilai RCAnya total sebesar 0,65 dengan komoditas unggulan yang sama. Sedangkan untuk Filipina terjadi penurunan daya saing menjadi 1,60 tetapi komoditas unggulan bertambah yang tadinya hanya empat (4) bertambah menjadi enam (6) komoditas. Singapura nilai RCA nya turun menjadi 3,24 dengan komoditas unggulan yang jumlahnya tetap. Untuk negara Malaysia, nilai RCA nya turun menjadi 1,22 yang tadinya bernilai 1,30 namun komoditas yang berdaya saing bertambah jumlahnya menjadi 3 komoditas. Untuk China sendiri nilai rata-rata RCA nya $<1$ namun komoditas unggulannya berjumlah lima komoditas. Hal ini menunjukkan bahwa dengan masuknya China ke dalam arus perdagangan di lingkup negara-negara ASEAN menyebabkan daya saing produk perikanan Indonesia meningkat. Ini dapat menjadi hal positif dari adanya ACFTA yang telah berjalan.

\section{KESIMPULAN DAN IMPLIKASI KEBIJAKAN}

\section{Kesimpulan}

Keunggulan komparatif produk perikanan Indonesia masih bertumpu pada produk ikan segar sedangkan untuk produk yang memiliki nilai tambah kurang memiliki keunggulan komparatif sehingga kurang memiliki daya saing. Indonesia memiliki keunggulan komparatif untuk komoditas HS 03 (fish, crustaceans, molluscs, aquatic invertebrates), HS 710110 (Pearls natural, not permanently mounted or set), HS 710121 (pearls cultured unworked) dan HS 121220 (seaweeds and other algae). Secara keseluruhan komoditas Indonesia 
masih memiliki keunggulan komparatif karena memiliki nilai lebih dari 1. Ketika China masuk ke dalam arus perdagangan produk perikanan di lingkup negara-negara ASEAN menjadikan terdorongnya nilai RCA produk perikanan Indonesia.

\section{Implikasi Kebijakan}

ACFTA menjadikan nilai produk perikanan Indonesia lebih berdaya saing. Peningkatan daya saing dapat dilakukan dengan peningkatan mutu produk ekspor. Pengambil kebijakan hendaknya lebih memperhatikan produk perikanan yang memiliki nilai tambah dalam rangka peningkatan daya saing dan nilai ekspor perikanan.

\section{DAFTAR PUSTAKA}

Annonimous. 2009. Indonesian Fisheries Book. Ministry of Marine Affairs and Fisheries - Japan International Cooperation Agency (JICA). 84 Hal.
Asnawi dan Sastrawidjaja. 2007. Permintaan Komoditas Perikanan Indonesia: Trend Konsumsi, Ekspor dan Mekanisme Harga. Potret dan Strategi Pengembangan Perikanan Tuna, Udang dan Rumput Laut Indonesia. Balai Besar Riset Sosial Ekonomi Kelautan dan Perikanan. Jakarta. hal 67-80.

Balassa, B. 1965. Trade Liberalization and Revealed Comparative Advantage. The Manchester School, 33, 99-123 pp.

Karim, M. 2008. Menyoal Revitalisasi Perikanan. http://commit- Indonesia. blogspot. com/2008/02/menyoal-revitalisasiperikanan.html. Diakses tanggal 22 Maret 2010.

Syah, H. 2000. Analisis Keunggulan Komparatif Komoditas Ekspor Non Migas Kabupaten Tangerang. Tesis Ilmu Administrasi Pasca Sarjana Fakultas IImu Sosial dan IImu Politik Universitas Indonesia. Jakarta. $116 \mathrm{Hal}$.

UN Comtrade. Data Nilai Ekspor Perikanan Negara-Negara Anggota ASEAN Dan China Tahun 2000 hingga 2008. http:// comtrade.un.org/. Diakses tanggal 10 Desember 2009. 


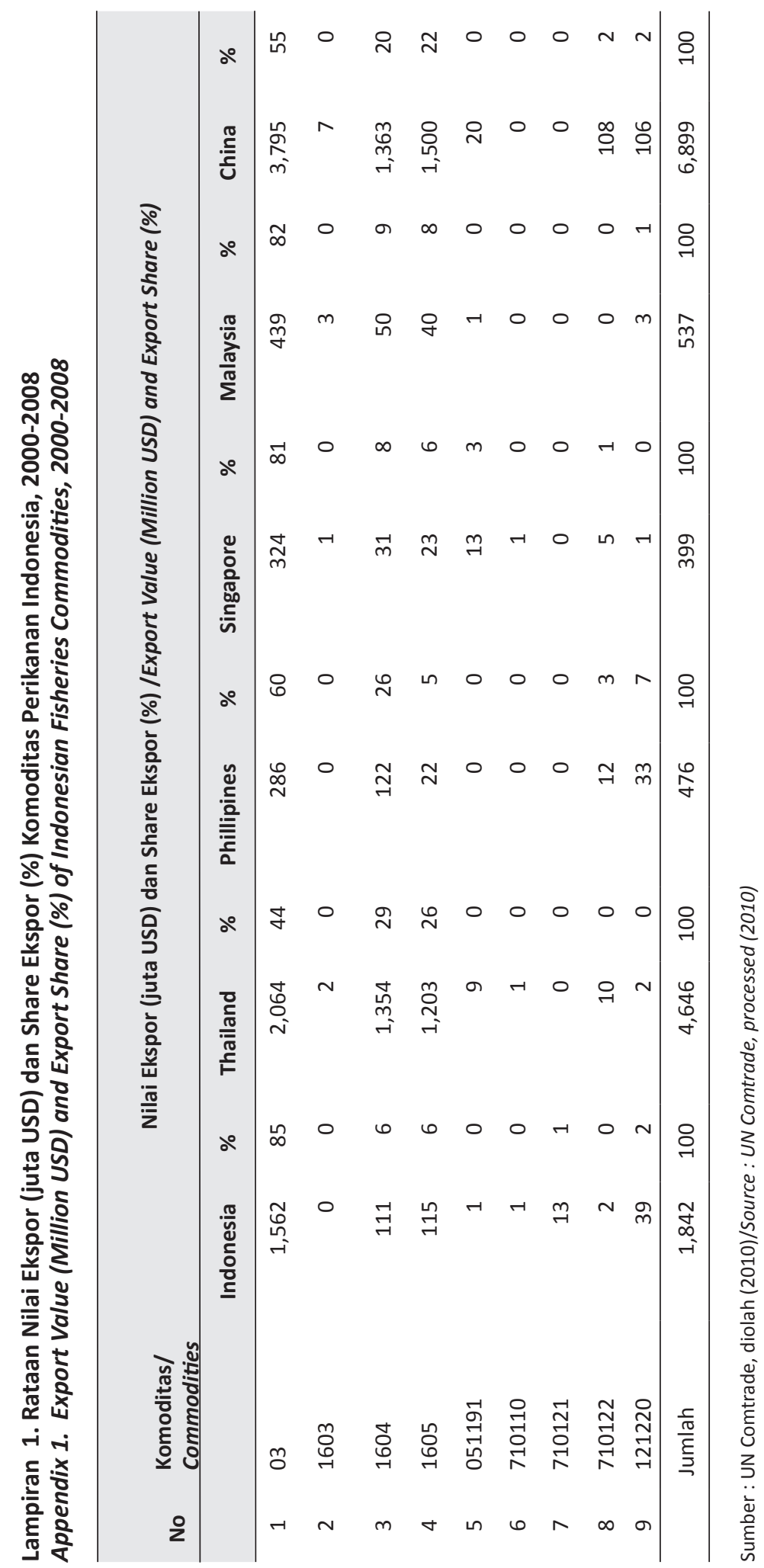

